\title{
De Democratisering van het Ressentiment; Emancipatie en Onbehagen in de Nederlandse Politiek
}

Citation for published version (APA):

Koenis, J. P. (2012). De Democratisering van het Ressentiment; Emancipatie en Onbehagen in de Nederlandse Politiek. Maastricht University. https://doi.org/10.26481/spe.20120216jk

Document status and date:

Published: 16/02/2012

DOI:

10.26481/spe.20120216jk

Document Version:

Publisher's PDF, also known as Version of record

\section{Please check the document version of this publication:}

- A submitted manuscript is the version of the article upon submission and before peer-review. There can be important differences between the submitted version and the official published version of record.

People interested in the research are advised to contact the author for the final version of the publication, or visit the DOI to the publisher's website.

- The final author version and the galley proof are versions of the publication after peer review.

- The final published version features the final layout of the paper including the volume, issue and page numbers.

Link to publication

\footnotetext{
General rights rights.

- You may freely distribute the URL identifying the publication in the public portal. please follow below link for the End User Agreement:

www.umlib.nl/taverne-license

Take down policy

If you believe that this document breaches copyright please contact us at:

repository@maastrichtuniversity.nl

providing details and we will investigate your claim.
}

Copyright and moral rights for the publications made accessible in the public portal are retained by the authors and/or other copyright owners and it is a condition of accessing publications that users recognise and abide by the legal requirements associated with these

- Users may download and print one copy of any publication from the public portal for the purpose of private study or research.

- You may not further distribute the material or use it for any profit-making activity or commercial gain

If the publication is distributed under the terms of Article $25 \mathrm{fa}$ of the Dutch Copyright Act, indicated by the "Taverne" license above, 


\section{De democratisering van het ressentiment}

Emancipatie en onbehagen in de Nederlandse politiek

Inauguratie van Prof. dr. Sjaak Koenis, benoemd tot bijzonder hoogleraar Sociale Filosofie in de Faculteit der Cultuur- en Maatschappijwetenschappen op donderdag 16 februari 2012 in de Aula van de Universiteit Maastricht, Minderbroedersberg 4-6 te Maastricht.

Mijnheer de Rector,

Lieve familie en vrienden,

Beste collega's en bekenden,

Geachte overige aanwezigen,

1.

Het zal niemand ontgaan zijn dat het politieke klimaat de laatste jaren bijzonder guur is geworden. ${ }^{1}$ Veel mensen zijn tegenwoordig boos, op de overheid, op de politieke en culturele elite, op de banken, op elkaar. Zij uiten hun boosheid op talloze manieren, vooral via nieuwe sociale media zoals GeenStijl die een geschikte uitlaatklep vormen voor de anonieme of halfanonieme expressie van onbehagen. Een aardig voorbeeld, niet afkomstig uit een nieuw maar een oud medium, Dagblad De Limburger, in de vorm van een strip: komt een vrouw bij een gemeenteloket, zegt de ambtenaar: "U moet nog 3576 euro aan openstaande boetes betalen, mevrouw." Zegt de vrouw: "Wat??? Daar komen jullie nu pas mee?! Het is toch van

\footnotetext{
${ }^{1}$ Ik dank René Gabriels, Amanda Kluveld, Janet Schimmel, Jan de Roder en Rein de Wilde voor hun commentaar op een eerdere versie van deze rede.
} 
de zotte dat jullie dat zo laten oplopen!" En ze vervolgt: "Zitten jullie de hele dag te slapen of zo van mijn belastingcenten?!"

Wat is hier aan de hand? Deze mevrouw is boos op de prioriteiten die de overheid stelt. Dat ze zélf ook deel van het probleem is, wil er bij haar niet in. Zulke kortzichtige boosheid kan men zeker niet alle burgers in Nederland aanwrijven, maar uit onderzoek van het Sociaal en Cultureel Planbureau over de stemming in Nederland blijkt wel dat deze mevrouw net als veel andere burgers de problemen vooral buiten zichzelf plaatsen: 'met mij gaat het goed, met ons gaat het slecht.' ${ }^{2}$

Zijn mensen tegenwoordig bozer dan ze vroeger waren? Moeilijk te zeggen: hoe zou je zoiets kunnen meten? Wel herinner ik me dat de journalist Henk Hofland in Tegels lichten, het boek uit 1972 over het naoorlogse herstel van 'Het Bestel' in Nederland, verwijst naar wat hij 'de stoottroepen van de rollende waanzin' noemt, de harde kern van gekken, jodenhaters, dreigers, schelders en mensen die een doos uitwerpselen stuurden, zoals naar Mies Bouman, na een uitzending van het succesvolle Vara-programma Zo is het toevallig ook nog eens een keer over Beeldreligie. ${ }^{3}$ Ook toen, in 1963, waren veel mensen heel boos, maar het is mogelijk dat we er tegenwoordig door de nieuwe media meer van merken.

Veel mensen denken dat de huidige boosheid een teken is van het recente falen van de democratie. Dat falen zou dan blijken uit de opkomst van het populisme in de personen van Pim Fortuyn, Rita Verdonk en Geert Wilders. Zonder het populisme zou deze boosheid verdwijnen als sneeuw voor de zon. Ik denk dat deze mensen oorzaak en symptoom met elkaar verwarren. Wat je ook veel hoort is dat met name de PVV van Wilders een bedreiging vormt voor de democratie. Volgens Rob Riemen van het Nexus-Instituut uit Tilburg worden we zelfs geconfronteerd met een nieuwe opleving van het fascisme. ${ }^{4}$ Ik denk dat er iets anders aan de hand is. Het populisme is niet de oorzaak van de huidige woede, maar geeft er wel uitdrukking aan. Maar wat belangrijker is: de boosheid is volgens mij niet het gevolg van de bedreiging of het falen van de democratie, maar juist het gevolg van het succes van de democratie.

\footnotetext{
2 Paul Dekker \& Josje den Ridder (red.)(2011), Stemming onbestemd. Tweede verdiepingsstudie Continu Onderzoek Burgerperspectieven (Den Haag: Sociaal en Cultureel Planbureau, p. 11.

${ }^{3}$ Henk Hofland (1986[1972]), Tegels lichten, of ware verhalen over de autoriteiten in het land van voldongen feiten, Bert Bakker: Amsterdam, p. 184.

${ }^{4}$ Rob Riemen (2010), De eeuwige terugkeer van het fascisme, Amsterdam: Atlas.
} 
Hoe kan boosheid nu het gevolg zijn van het succes van de democratie? Democratie associëren we toch met mooie dingen als tolerantie, vrijheid en gelijkheid? Met het streven naar emancipatie? Zijn er juist niet ontzettend veel mensen in de wereld, denk aan de Arabische lente, die boos zijn omdat ze te weinig democratie hebben? Die mooie dingen vormen inderdaad een belangrijk aspect van democratie, en geven ons ook voldoende reden om democratie na te streven. Maar er zit ook een meer duistere kant aan democratie, een die progressieven liever niet onder ogen zien, omdat zij democratie vereenzelvigen met deze mooie zaken en de problemen van de democratie willen oplossen met méér democratie. Die duistere kant is wél altijd opgemerkt door conservatieve denkers, eigenlijk al vanaf Plato die in Boek 8 van de Politeia de democratie spottend en als het ware preluderend op onze multiculturele samenleving vergelijkt met 'een mengelmoes van karakters die schittert als bonte kleren met een veelkleurig bloemenpatroon' en die opmerkt dat democratie leidt tot de ondermijning van het gezag van leiders en ouders en tot het mateloze zwelgen in egoïstische verlangens waar de gemeenschap niets aan heeft. ${ }^{5}$ Waar ik op doel is dat democratie ook afgunst en ressentiment voortbrengt. Democratie heeft een Januskop: het ene gezicht toont democratie als een bron van emancipatie en 'empowerment'; het andere toont democratie als een bron van ressentiment, dat zich uit in afgunst en boosheid.

Waarom zou democratie een bron van ressentiment zijn? Om dit te begrijpen moeten we ons in de woorden van de Franse historicus Ferdinand Braudel op la longue durée, dus op de lange duur richten, in het bijzonder op twee processen: zowel toenemende (stands)gelijkheid als toenemende onttovering. Een groot deel van mijn oratie zal ik besteden aan de bespreking van deze twee processen. Aan het eind zal ik de stelling verdedigen dat deze twee processen in de laatste decennia elkaar als botsende weersystemen zijn gaan versterken. Het is alsof we gevangen zitten in een 'perfecte storm' waarbij aan de ene kant de bronnen van emancipatie uitgeput lijken te zijn, terwijl aan de andere kant het ressentiment in volle sterkte naar buiten treedt: we beleven nu de democratisering van het ressentiment.

2.

Toenemende gelijkheid. Hoe leidt toenemende gelijkheid nu tot ressentiment? Ik kan dit niet beter uitleggen dan Alexis de Tocqueville dit heeft gedaan in de jaren dertig van de negentiende eeuw in zijn beroemde boek Over de democratie in Amerika. Hij wijst erop dat

\footnotetext{
${ }^{5}$ Plato (2010), Politeia (De ideale staat), Amsterdam: Athenaeum - Polak \& Van Gennep, p. 303.
} 
democratische instellingen het gevoel van afgunst in het menselijk hart tot zeer grote ontwikkeling brengen. Dat is volgens Tocqueville niet zo omdat democratische instellingen mensen de middelen bieden om de anderen te evenaren, maar omdat deze middelen voortdurend tekort schieten. Democratische instellingen wekken de hartstocht voor gelijkheid (in de betekenis van gelijkwaardigheid) op en wakkeren die aan, maar kunnen deze hartstocht nooit volledig bevredigen. De standen waaruit de oude samenleving bestond worden in een democratie gelijk, maar de prijs is dat afgunst, haat en minachting voor de buurman en hoogmoed en overdreven zelfvertrouwen zich van mensen meester maken. ${ }^{6}$

Democratie is een maatschappijvorm (dus meer dan louter een politieke institutie) waarin mensen formeel aan elkaar gelijk zijn. Daarin verschilt de democratie van oudere standensamenlevingen waarin ongelijkheid geïnstitutionaliseerd was en mensen ook letterlijk 'hun plek wisten'. Het is in Nederland de democratisering geweest die in een paar etappes de oude standensamenleving heeft ondermijnd. Een van die etappes is de verzuiling geweest. De zuilen vormden voor sommige groepen een middel tot emancipatie, maar tevens werden de grote tegenstellingen die aan de basis bestonden, aan de top gepacificeerd door een hiërarchisch ingestelde elite. In de ontzuiling die Hofland in Tegels lichten documenteert, gaat de ontmanteling van het regentendom hand in hand met het luidruchtig naar buiten treden van de boze burger. Emancipatie en ressentiment, de twee gezichten van democratie, worden hier mooi zichtbaar.

Toenemende gelijkwaardigheid is steeds hand in hand gegaan met de ervaring van ongelijkheid, eenvoudigweg omdat mensen verschillen in talent, energie en in wat het lot voor hen in petto heeft. De wrijving tussen formele gelijkheid en feitelijke ongelijkheid wordt op de spits gedreven in onze 'diplomademocratie' waarin een premie staat op 'excellentie'. ${ }^{7}$ De tweedeling waar Joop den Uyl in de jaren zeventig van de vorige eeuw over sprak, lijkt zich in een andere gedaante voltrokken te hebben: niet die tussen traditionele klassen maar die tussen hoger - en lager opgeleiden. Deze wrijving zorgt voor veel van de maatschappelijke hitte die naar buiten komt in de vorm van ressentiment.

Dé klassieke auteur over ressentiment is Friedrich Nietzsche die in De genealogie van de moraal laat zien dat ressentiment zelf scheppend wordt en waarden voortbrengt: "Het

\footnotetext{
${ }^{6}$ Alexis de Tocqueville, (2011[1835; 1840], Over de democratie in Amerika, Rotterdam: Lemniscaat, p. 218 en 448.

${ }^{7}$ Mark Bovens (2011), Diplomademocratie: over de spanning tussen meritocratie en democratie, Amsterdam: Bakker.
} 
ressentiment van wezens aan wie de werkelijke reactie, die van de daad, onthouden is en die zich alleen door een denkbeeldige wraak schadeloos kunnen stellen."8 Het gaat bij ressentiment om een herhaald doorleven en beleven van een vijandige emotionele reactie jegens iemand anders of een groep anderen, waardoor die emotie steeds intenser wordt, zeker wanneer de betrokkenen niet in staat zijn iets aan hun eigen positie te doen. Voor Nietzsche was het christendom typisch een ressentimentsbeweging: christenen omarmen de slavenmoraal uit onvermogen om weerstand te bieden aan de bron van hun ellende; de zwakkeren koesteren haatgevoelens jegens de sterkeren, maar komen niet verder dan 'imaginaire wraak'.

De filosoof Peter Sloterdijk volgt Nietzsche op dit spoor: hij spreekt in het geval van het communisme, socialisme en feminisme van woedecollectieven die gedreven worden door ressentiment. ${ }^{9}$ Sloterdijk erkent dat ressentiment niet altijd gesmoord hoeft te worden in machteloosheid, maar toch volg ik liever de filosoof Max Scheler omdat hij meer oog heeft voor het eerder genoemde ambivalente karakter van democratie: ressentiment komt voort uit boosheid over ongelijkheid die als onrechtvaardig wordt ervaren, maar kan zich op verschillende manieren uiten. De sociale woede kan zich ontladen in creatieve energie ter verandering van de maatschappij, via wat Scheler 'ontladingsmechanismen' noemt, zoals parlementair debat, sociale actie van emancipatiebewegingen, rechtspraak of zelfs - toen nog wel - het duel. De woede kan ook tot uiting komen in de vorm van wat Scheler ressentimentskritiek noemt. Hiervan is sprake als het verhelpen van de toestand die als kwalijk wordt ervaren geen soelaas biedt, maar integendeel juist zelf onbehagen teweeg brengt. Dat onbehagen ontstaat omdat zo'n poging om iets aan het probleem te doen, een einde zou maken aan het groeiende lustgevoel waarmee het schelden en tieren gepaard pleegt te gaan. Dat Wilders niet geïnteresseerd is in de hervorming van de islam, duidt erop dat zijn islamkritiek ressentimentskritiek is. ${ }^{10}$ En ander voorbeeld van ressentiment dat men wellicht eerder bij links aantreft, betreft de salarissen van managers in de publieke sector. Als straks al deze managers onder de Balkenende-norm zitten, zal het linkse ressentiment op iets anders gericht moeten worden. Ook in dit voorbeeld zitten twee kanten aan de boosheid over deze hoge salarissen: enerzijds ontlaadt het zich in pogingen om deze salarissen daadwerkelijk aan de norm aan te passen, maar anderzijds zal het succes van zulke maatregelen weer een nieuwe bron van onbehagen zijn.

\footnotetext{
${ }^{8}$ Friedrich Nietzsche (2000[1887]), De genealogie van de moraal, Amsterdam: De Arbeiderspers, p. 29.

${ }_{9}^{9}$ Peter Sloterdijk (2007[2006]), Woede en tijd, Amsterdam: Sun, p. 30.

${ }^{10}$ Max Scheler (2008), Het ressentiment in de moraal, Amsterdam: Boom, p. 19/20.
} 
We kunnen dus met Scheler stellen dat ressentiment zich op twee manieren kan uiten: het kan leiden tot sociale actie die gericht is op het aanpakken van de als kwalijk ervaren toestand, of het kan de vorm aannemen van ressentimentskritiek die gericht is op het in stand houden van de boosheid, en niet op het oplossen van het onderliggende probleem. Met behulp van dit onderscheid krijgen we meer oog voor het dubbelzinnige karakter van sociale bewegingen zoals het socialisme of het feminisme: naast emancipatiebewegingen zijn dit ook altijd ressentimentbewegingen geweest; emancipatie en ressentiment zijn inniger met elkaar verbonden dan veel mensen willen toegeven. Ressentiment levert de brandstof voor de motor van de emancipatie, het is de zuurstof die de emancipatie-idealen voedt. Dezelfde dubbelzinnigheid geldt mijns inziens ook voor het hedendaagse populisme: populisme kan men niet wegzetten als louter een rancunebeweging. Toegegeven: Geert Wilders is een meester in ressentimentskritiek. Neem bijvoorbeeld zijn beruchte voorstel voor een 'kopvoddentaks' of, heel recent, het meldpunt voor Oost-Europeanen. ${ }^{11}$ Tegelijk kondigt zich met het populisme een nieuwe vorm van emancipatie aan, die van de boze burgers. Deze burgers breken met wat zij ervaren als misplaatste, door een linkse elite opgelegde politieke correctheid die hen de mond snoerde. Luister maar naar Joost Eerdmans die op doordeweekse avonden nadrukkelijk het 'andere' geluid van Wakker Nederland laat horen.

\section{3.}

Ik had het over het streven naar gelijkheid. Maar ressentiment als product van toenemende gelijkheid heeft niet alleen betrekking op de positie van mensen op de maatschappelijke ladder, dus op wat de sociale kwestie wordt genoemd. Het gaat ook om wat ik de culturele kwestie wil noemen. Daarmee kom ik op het tweede proces, dat van onttovering.

Ressentiment tast ook iedere geleding van de cultuur aan, of het nu gaat over het onderscheid tussen hoge en lage cultuur, of de tegenstellingen tussen levensbeschouwingen. De verdedigers van de hoge cultuur zijn bang voor de commerciële massacultuur. Zij hebben het onderscheid tussen hoge en lage cultuur nodig om hun positie te markeren. Distinctiedrift zouden we in de geest van de socioloog Bourdieu kunnen zeggen. Tegenover deze pleitbezorgers van de hoge cultuur zou je verwachten dat zich de verdedigers van de lage cultuur opstellen, maar die zijn er helemaal niet. Er zijn wel veel mensen die het onderscheid

\footnotetext{
${ }^{11}$ Vgl. Jan de Roder (2010), 'U kunt bezwaar hebben tot u een ons weegt'; Geert Wilders' succesvolle politiek-voorbij-de-inhoud, Krisis. Tijdschrift voor actuele filosofie, Issue 2, p. 39.
} 
tussen hoog en laag afwijzen (bijvoorbeeld de bekende kunstcriticus Robert Hughes ${ }^{12}$ ) en er zijn ook mensen (bijvoorbeeld vertegenwoordigers van populistische partijen) die tegen elitekunst aanschoppen met het argument dat de gewone man daar helemaal niets aan heeft. Zo stelde de lijsttrekker van de PVV Sietse Fritsma bij de Haagse gemeenteraadsverkiezingen van 2010 voor de subsidie van onder andere het Residentie Orkest stop te zetten.

Wat opvalt is dat de woede van meerdere kanten komt: ressentiment is niet beperkt tot dragers van de lage cultuur. Bovendien wordt de strijd om cultuur gevoed door verschillende visies op wat de ideale gemeenschap is. Dat is het geval bij het debat over hoge en lage cultuur, maar ook bij de strijd tussen levensbeschouwingen en ideologieën die de Nederlandse democratie vorm heeft gegeven. In het eerste geval staat gecanoniseerde hoge cultuur tegenover populaire (massa)cultuur, in het tweede geval worden via levensbeschouwingen als het katholicisme of het humanisme en ideologieën als het socialisme of feminisme voorstellingen van de ideale gemeenschap inzet van politieke strijd. Die voorstellingen van een ideale gemeenschap zijn belangrijk omdat mensen behalve uit hun ressentiment ook uit deze voorstellingen de motivatie en energie putten voor hun strijd om emancipatie en verandering.

Het gaat mij er niet om partij te kiezen in deze strijd. Van belang is dat de wederzijdse sociale woede leidt tot nieuwe cultuurvorming, tot een productieve strijd om cultuur. In navolging van Nietzsche sprak de essayist Menno ter Braak in de jaren dertig van de vorige eeuw in dit verband van de emancipatie van het ressentiment: ressentiment leidt tot vooruitgang, tot nieuwe cultuurvorming, maar deze vooruitgang verschilt wel van die waar naïeve humanisten in zijn dagen over spraken. ${ }^{13}$ Zij geloofden - niet heel anders dan tegenwoordig de modernist Francis Fukuyama - dat toename van kennis en materiële techniek vanzelf leidt tot vooruitgang van de mensheid. De cultuurvorming die het gevolg is van deze emancipatie van het ressentiment tast de canonieke positie van de hoge cultuur aan. En niet alleen die van de hoge cultuur; ook die van de gevestigde levensbeschouwingen en ideologieën. Daarmee bedoel ik dat de exclusieve waarheidsaanspraken die verbonden waren met de hoge cultuur en met deze levensbeschouwingen en ideologieën werden ondermijnd. Deze strijd om cultuur leidt met andere woorden tot een onttovering van cultuur. Het gaat er niet om dat bepaalde vormen van 'hoge' cultuur niet meer belangrijk zouden zijn. Of dat

\footnotetext{
12 Robert Hughes (1996). The myths of high and low. ISPA keynote address International Society for the Performing Arts Foundation, New York, 15 December 1996.

${ }^{13}$ Menno ter Braak (1980[1937]), Verzameld werk, deel 3, Amsterdam: G.A. van Oorschot, p. 356, 363.
} 
levensbeschouwing of ideologie er niet meer toe zouden doen. Waar het wel om gaat is de erkenning van een radicaal pluralisme, waarbij niemand meer zijn visie op de ideale gemeenschap en zijn waarden aan anderen kan opleggen. Wat dit betekent voor het karakter van de democratie heb ik in mijn boek Het verlangen naar cultuur proberen uit te werken. ${ }^{14}$ Hier beperk ik mij tot de stelling dat wie de emancipatie van het ressentiment serieus neemt, zich ook zou moeten realiseren dat de klassieke argumenten voor verheffing niet meer gelden. Die klassieke argumenten leunden op het idee dat er overeenstemming bestond over waar het bij verheffing inhoudelijk om zou moeten gaan en dat de culturele elite de mensen de weg daar naartoe zou wijzen. Die overeenstemming is er nooit geweest (of was in feite beperkt tot een kleine groep van ingewijden), maar wat de situatie tegenwoordig anders maakt is dat de culturele elite van zijn voetstuk is gehaald.

En geldt niet precies hetzelfde voor de politiek geladen notie van 'de Nederlandse cultuur'? Nogal wat mensen worden nerveus van het gegeven dat traditionele opvattingen over de Nederlandse cultuur tegenwoordig ter discussie staan. Hierbij gaat het niet om de vraag of Nederland wel of geen cultuur heeft, maar om het feit dat die traditionele noties door processen van globalisering en migratie sterk onder druk zijn komen te staan. De strijd om cultuur speelt zich tegenwoordig af tussen kosmopolieten en antikosmopolieten, en zal er toe leiden dat nieuwe opvattingen over onze cultuur of gemeenschap veld zullen winnen. Maar ook hier zal deze strijd leiden tot een onttovering van het idee van één Nederlandse cultuur. Dat zoveel mensen nieuwe vormen van betovering denken te vinden in de canon van dorp, stad, regio, in het Nederlands landschap, de Nederlandse klassieke muziek, de Nederlandse geschiedenis en literatuur, is geen weerlegging van deze stelling, maar vormt juist de bevestiging ervan. Het Rijksmuseum en al die andere historische musea die Nederland rijk is, waren bij elkaar niet genoeg om Nederlanders (en toeristen) over onze geschiedenis te informeren. Nee, er moest per se een nieuw Nationaal Historisch Museum komen om tegemoet te komen aan ons verlangen om onze cultuur en geschiedenis te monumentaliseren in de zin van Nietzsche's Over nut en nadeel van de geschiedenis voor het leven. $\mathrm{Nu}$ dit museum van de baan is, zal het verlangen zich ongetwijfeld aan nieuwe zaken hechten.

Terwijl de sociale kwestie in Nederland gewoonlijk wordt gesitueerd aan het eind van de negentiende eeuw, geldt voor de culturele kwestie dat zij tot op de dag van vandaag doorwerkt, ook in de politieke strijd om de democratie. Ressentiment of sociale woede leidt

\footnotetext{
${ }^{14}$ Sjaak Koenis (2008), Het verlangen naar cultuur; Nederland en het einde van het geloof in een moderne politiek, Amsterdam: Van Gennep.
} 
ook tot een onttovering van cultuur. Hoe gaat dat in zijn werk? Steeds worden min of meer canonieke verbeeldingen van cultuur, van wie wij zijn, van de ideale gemeenschap, aangetast door het zuur van het ressentiment. Deze onttovering zullen sommigen alleen maar negatief duiden, als de teloorgang van de Nederlandse cultuur en het verlies van wat zij als het monumentale verleden van Nederland zullen zien. Populisten bijvoorbeeld zijn vergeefs op zoek naar een hartland, dat uiteraard alleen als mythe bestaat. Toch dragen ook zij ongewild met zulke nieuwe interpretaties van cultuur bij aan de 'creatieve destructie' van deze monumentale cultuur, en daarmee aan een nieuwe fase in het debat over de Nederlandse identiteit. Ik vind het wel jammer dat tegenover deze populistische mythe van het hartland zo weinig andere beelden worden geplaatst van wat de historicus Huizinga ons nationaal besef heeft genoemd. De enige uitgewerkte visie die mij voor de geest komt is die van de filosoof Ad Verbrugge, maar zijn stelling dat het protestantisme weer de kern van onze natie moet worden, klinkt niet erg bemoedigend voor alle niet-protestanten en mensen die Nederland domineesland nu eindelijk eens achter zich willen laten. ${ }^{15}$

\section{4.}

Maar laat ik nu een eerdere fase van dit proces van onttovering van cultuur in de Nederlandse democratie de revue laten passeren, om een indruk te geven van de effecten van deze onttovering . Een groot deel van de twintigste eeuw laat zich samenvatten onder de noemer van de erosie van een collectief gedeelde levensbeschouwing of ideologie. Er is tegenwoordig onder historici weer veel discussie over verzuiling en ontzuiling, maar de kern van de zaak lijkt mij dat in de afgelopen eeuw belangrijke segmenten van de Nederlandse samenleving levensbeschouwelijk en/of ideologisch georganiseerd waren. Ik kom zelf uit een NoordHollands katholiek milieu en heb op een katholiek internaat gezeten. Als ik nu vanuit belangstelling voor mijn wortels teruglees hoe snel deze zuil in de loop van de twintigste eeuw verpulverd is, dan kan ik dat alleen maar met verbijstering aanzien. De katholieken voelden zich gedurende het interbellum sterk genoeg om zelfbewust naar buiten te treden. Men had het gevoel dat de emancipatie voltooid was en men wees dan trots - bijvoorbeeld op de vestiging van de katholieke Universiteit van Nijmegen in 1923. De publicist en latere hoogleraar Anton van Duinkerken vind ik een mooie representant van die fase van katholiek zelfbewustzijn. In zijn bekende debatten met Menno ter Braak viel hij niet alleen diens

\footnotetext{
${ }^{15}$ Ad Verbrugge (2004), Tijd van onbehagen, Amsterdam: Sun.
} 
nihilisme aan, maar hij wees ook op de mogelijkheid dat de Europese cultuur weer een hecht fundament zou kunnen vinden in de katholieke wereldbeschouwing die trouw aan een van de betekenissen van 'katholiek' weer iedereen omvattend zou kunnen worden. ${ }^{16}$ In die dagen was de positie van de democratie eigenlijk zo wankel dat niet alleen extremisten maar ook veel gevestigde intellectuelen zoals Huizinga met een zekere dedain over democratie spraken.

Vergelijk dit zelfvertrouwen van Anton van Duinkerken nu eens met de tobberige discussie die twee bekende zonen van de katholieke traditie Godfried Bomans en Michel van der Plas in 1969 over het katholicisme publiceren. Zij voelen rancune tegen het instituut van de katholieke kerk omdat zij te lang bang zijn gemaakt met de hel. Zij voelen zich suppoosten van een museum, maar kunnen zich tegelijk niet voorstellen dat een traditie van tweeduizend jaar die prachtige kathedralen en beschaving heeft voortgebracht, geen elementen van waarheid zou bevatten. De onttovering van het katholicisme komt mooi tot uitdrukking als Bomans in een verwijzing naar de afschaffing van het Latijn (als 'vocale wierook') constateert dat het floers van het katholicisme werd afgerukt. ${ }^{17}$ Waar het mij om gaat: de culturele kwestie betrof toen de strijd tussen humanisten, protestanten, socialisten en katholieken. Niemand heeft die strijd gewonnen, maar alle partijen zijn door die strijd wel veranderd. Zij hebben hun 'geloofsfundamenten' moeten loslaten of herzien en de warmte van hun groep voelen uitdoven.

Mijn tweede voorbeeld betreft de sociaaldemocratie. Terwijl vóór de Tweede Wereldoorlog onder veel intellectuelen van diverse pluimage scepsis bestond over de waarde en overlevingskansen van de democratie, wordt na de oorlog 'het einde van de ideologie' verbonden met de omarming van de democratie. In de Nederlandse politiek zien we de verschillende fasen van deze ontwikkeling door de lotgevallen van de sociaaldemocratie te volgen. De vooroorlogse SDAP manifesteerde zich in alle opzichten als een levensbeschouwing, terwijl de doorbraak vlak na de oorlog leidde tot een levensbeschouwelijk opener sociaaldemocratische partij, de PvdA. De verdere cultuurstrijd heeft echter ook deze PvdA niet onaangeroerd gelaten: alle oude socialistische veren werden in de loop van de tijd geplukt totdat in de jaren negentig een partij overbleef die niet alleen zijn ideologie maar ook zijn oude emancipatie-idealen was kwijtgeraakt.

\footnotetext{
${ }^{16}$ Zie Ewoud Kieft (2006), Het plagiaat; de polemiek tussen Menno ter Braak en Anton van Duinkerken, Nijmegen: Vantilt, p. 315.

17 Godfried Bomans en Michel van der Plas (1969), In de kou; Godfried Bomans en Michel van der Plas over hun roomse jeugd en hoe het hun verder verging, Bilthoven: Ambo, pp. 95, 101, 130, 167.
} 
Zulke strijd zou een modernist of evolutionist misschien opvatten als een loskomen van oude belemmerende ketens op weg naar meer rationalisering en individualisering, maar er zijn in die cultuurstrijd ook zaken verloren gegaan die we nu node missen. Ten eerste zijn deze ideologische bewegingen erin geslaagd om de woede van hun achterban op een constructieve manier om te zetten in een beter perspectief voor hun mensen. Emancipatie betekende in die dagen nogal wat, het was een begrip dat met veel draden aan allerlei maatschappelijke praktijken verbonden was, ook al verschilden die van groep tot groep en werkte men elkaar zoveel mogelijk tegen. Maar deze bewegingen deden nog iets anders wat volgens mij nu teveel over het hoofd wordt gezien: voor mensen die bij deze emancipatierace niet helemaal of helemaal niet vooraan zouden eindigen, hadden deze levensbeschouwingen of ideologieën ook een verhaal: we zijn zó geneigd om deze oude ideologieën vanuit een modernistisch perspectief te bekijken, dat we onvoldoende zien dat ook diegenen die de race niet zouden winnen van een plaats werden voorzien. Ook al zat niet iedereen vooraan, mensen hadden wel een plaats, en konden daar ook respect aan ontlenen. Peter Sloterdijk schrijft terecht dat het juist de moderniteit is die de verliezer heeft uitgevonden, ook al bekommert hij zich verder niet bijster om deze verliezers. Ik onderschrijf het pleidooi van Tjalling Swierstra en Evelien Tonkens om te zoeken naar nieuwe vormen van respect in een diplomademocratie ${ }^{18}$, en ik geloof dat ook historisch onderzoek naar manieren waarop klassieke sociale bewegingen met dit probleem omgingen hierbij nuttig kan zijn. Trots is niet alleen voor de besten weggelegd.

5.

De twee processen van toenemende gelijkheid en onttovering zijn elkaar in de laatste decennia gaan versterken. Toenemende onderlinge gelijkheid en de teloorgang van traditionele gemeenschapsidealen versterken elkaar sinds een aantal decennia. Het zijn namelijk niet alleen de verliezers van de moderniteit die zich wenden tot populistische partijen. Ook veel leden van de geëmancipeerde middenklassen voelen zich meer thuis bij deze partijen dan bij de klassieke middenpartijen. Hun ressentiment is niet hetzelfde als dat van de verliezers van de moderniteit. Het succes van de emancipatie heeft geen einde gemaakt aan het ressentiment, maar heeft juist bijgedragen aan wat ik de democratisering van het

18 Tsjalling Swierstra \& Evelien Tonkens (red.) De beste de baas; prestatie, respect en solidariteit in een meritocratie, Amsterdam: Amsterdam University Press. 
ressentiment wil noemen. Terwijl in eerdere fasen van de Nederlandse democratie emancipatie en ressentiment nauw met elkaar verbonden waren, op zijn minst in de klassieke emancipatiebewegingen, waardoor ressentiment over achterstelling de benodigde politieke energie schiep om te vechten voor emancipatie, zijn emancipatie en ressentiment nu ontkoppeld. Veel gevestigde burgers zijn niet meer in staat de strijd van (veelal islamitische) migranten en hun kinderen om in Nederland een plek te verwerven te herkennen als een emancipatiestrijd. Terwijl in de dagen van de verzuiling nog een - wellicht gemankeerd besef van pluriformiteit heerste, overheerst tegenwoordig een benauwend streven naar culturele homogeniteit. En onder die deken van homogeniteit gaat een statusgevoelige samenleving schuil die in 1830 al door Tocqueville is voorspeld. Hij meende dat in democratische tijden de mensen niets hebben wat hen scheidt of op hun plaats houdt. Zij vinden met buitengewone snelheid de weg omhoog of omlaag. Alle klassen zien elkaar, imiteren elkaar en zijn afgunstig op elkaar. Dit brengt het volk op een massa ideeën, begrippen en verlangens die het niet zou hebben gehad als de rangen waren gesloten en de samenleving immobiel was geweest. ${ }^{19}$ Ziet $\mathrm{u}$ nu ook onwillekeurig de beelden van $\mathrm{tv}$ programma's waarin iedereen kan gaan voor zijn 15 minuten van faam? Omdat in deze statusgevoelige samenleving inspanning en beloning niet meer duidelijk met elkaar verbonden zijn, is de reikwijdte van ressentiment vergroot. Ressentiment is in de woorden van Brian Turner, die wijst op de belangrijke rol van de nieuwe media, een geïndividualiseerde emotie of dispositie geworden, die misschien wel door veel mensen gedeeld wordt, maar die zichzelf niet leent voor collectieve actie. ${ }^{20}$ Iedereen is boos op iedereen, en maakt er ook een punt van dit te tonen. Of, zoals Arnon Grunberg in de Volkskrant van 14 oktober 2011 schreef: "De burgers zijn niet boos omdat hun onrecht is aangedaan, maar omdat de woede hun leven zin geeft."

Aan het slot van deze rede wil ik een paar conclusies trekken. Ik heb willen laten zien dat het populisme van tegenwoordig past in de lange termijnontwikkeling van de Nederlandse democratie (en niet alleen die van Nederland, maar dat laat ik maar even zitten.) Om te begrijpen waar het hedendaagse onbehagen vandaan komt, heb ik sterk ingezoomd op ressentiment als een belangrijk produkt van democratisering. Die boosheid en dat ressentiment zullen niet weggaan, dus mijn advies zou zijn: wen er maar aan en leer er (beter) mee om te gaan. Politici, maar ook gezagsdragers op andere maatschappelijke terreinen, van

\footnotetext{
${ }^{19}$ Op. Cit., p. 479

${ }^{20}$ Brian Turner (2011), Max Weber and the spirit of resentment: The Nietzsche legacy, Journal of Classical Sociology, 11(1), 75-92, p. 86 ev.
} 
leraren tot rechters, van ouders tot vakbondsleiders, allemaal zullen zij moeten leren omgaan met het gegeven dat hun gezagsaanspraken altijd ter discussie kunnen en zullen worden gesteld. Dat is democratie. Burgers, op hun beurt, zouden misschien een betere balans kunnen zoeken tussen het uiten van hun boosheid en het meewerken aan oplossingen. Het probleem van die mevrouw aan het begin van mijn oratie is niet dat ze boos is, maar dat ze niet wil zien dat ze zelf deel van het probleem is. Burgerschap vergt tegenwoordig veel meer reflexiviteit dan vroeger. Die strekt zich ook uit over kwesties van zingeving: anders dan vroeger moeten mensen de last van zingeving veel meer zelf op hun schouders nemen, en dat is niet eenvoudig. Zeker niet voor al die mensen die wel hun best doen, maar die dan toch niet tot de besten zullen behoren. Ondanks alle aandacht in deze oratie voor ressentiment wil ik benadrukken dat we de twee kanten van democratie, bron van emancipatie, van 'empowerment' of - in de woorden van de filosoof Herman van Gunsteren ${ }^{21}$ - van vertrouwen aan de ene kant, en bron van ressentiment aan de andere kant, in hun onderlinge samenhang moeten bestuderen. Dat is wat de journalisten van De Limburger die de fraaie serie over Onbehagen in Limburg hebben gemaakt, in feite ook hebben gedaan. Onderzoek naar de onderlinge samenhang van die twee kanten van de democratie vormt ook de kern van mijn leeropdracht.

Aan het eind van deze rede wil ik graag enkele woorden van dank uitspreken.

Allereerst gaat mijn dank uit naar het College van Bestuur van de Universiteit van Maastricht dat heeft ingestemd met deze bijzondere leerstoel, en naar het Bestuur van de Faculteit der Cultuur - en Maatschappijwetenschappen, dat zich in de persoon van de decaan Rein de Wilde sterk heeft gemaakt voor de instelling ervan. Sinds ik in 1994 lid ben geworden van de Maastrichtse universitaire gemeenschap heb ik mij aan deze universiteit als een vis in het water gevoeld. Toen ik hier in Maastricht kwam kon ik al zwemmen, maar geleerd heb ik het in Groningen, van mijn promotoren Lolle Nauta en Gerard de Vries, en van de vrienden van de filosofenclub, onder wie ook Rein. Ik denk dat het vooral de gemeenschap van de faculteit is geweest die mij gevormd heeft tot de filosoof die ik nu ben: actuele politieke problemen onderwijzen en onderzoeken in interdisciplinair cultuurwetenschappelijk verband, met een passie voor politieke filosofie, een voorliefde voor een historisch perspectief op die

\footnotetext{
${ }^{21}$ Herman van Gunsteren (2006), Vertrouwen in democratie, Amsterdam: Van Gennep.
} 
problemen en een oriëntatie op het publieke debat. Ik bedank dan ook alle mensen in de faculteit die in al die jaren samen met mij opgezwommen hebben: niet alleen de wetenschappers maar ook de medewerkers die ons werk ondersteunen en niet te vergeten de studenten voor wie een belangrijk deel van ons werk bedoeld is. Bij de faculteit reken ik voor het gemak ook de collega's van het University College Maastricht met wie ik met veel plezier heb samengewerkt. In het bijzonder bedank ik de leden van de capaciteitsgroep Wijsbegeerte voor hun collegialiteit en het vertrouwen dat ze mij gaven toen ik een poos hun voorzitter was.

Ik sta ook buiten de faculteit bij veel mensen in het krijt. Ik kijk met plezier terug op het redactiewerk voor het tijdschrift Grafiet dat inmiddels niet meer bestaat, en op dat voor het tijdschrift Filosofie \& praktijk, dat in deze jaren van internationalisering eigenwijs verder gaat met het maken van mooie Nederlandstalige nummers over filosofische kwesties. Ik wil hier ook Pasi Saukkonen noemen, mijn Finse collega en vriend met wie ik met veel plezier heb samengewerkt. Misschien lukt het ons toch ooit een keer samen een boek te schrijven!

Ik vind het erg jammer dat mijn ouders dit niet hebben kunnen meemaken. Zij hebben een groot gezin opgevoed. Een gemeenschap op zich. Die spanning tussen gelijkheid en wedijver was ook terug te vinden in ons gezin. Juist dankzij die spanning hebben mijn ouders en broers en zussen voor mij de condities geschapen om een goede start in mijn leven te maken. Daar ben ik ze allemaal dankbaar voor. Ik wil ook de familie van Janet bedanken: ik heb me bij hen altijd heel thuis gevoeld. Ik wil mijn schoonvader Anton apart noemen. Als sociaaldemocraat van de oude stempel heeft hij zijn scepsis voor mensen van katholieke huize langzaam weten te overwinnen. Hij heeft niet alleen met ons meegeleefd, maar ook mijn schrijfsels indringend meegelezen. Claude et José, je sais que ça vous a etonné que parmi les barbares du nord on trouve des philosophes. Mais dans ses mots de remerciement vous deux aussi, vous méritez une place importante. Nous, Janet, moi et nos enfants, on a trouvé tant de chaleur, d'hospitalité chez vous et vous respirez tant le désir d' illumination et de connaissance, que ma confiance dans l'avenir de l' Europe est basée pour la plupart sur notre contact.

Van al mijn vrienden wil ik er twee bij naam noemen (in de hoop dat de anderen niet afgunstig zullen zijn!): Cees Vreugdenhil en Jan de Roder. Met Cees struin ik graag musea af, met Jan werk ik het meest intensief samen, in ons onderzoek naar het politieke essay en in het 
masteronderwijs. Maar mijn grootste maatje is Janet. Jij vormt samen met Rutger, Milou en Leon mijn kleinste gemeenschap waar ik het meeste aan verschuldigd ben.

Ik heb gesproken. 